Discussion Paper No. 15-087

Mobile Information and Communication Technologies, Flexible Work Organization and Labor Productivity: Firm-Level Evidence

Steffen Viete and Daniel Erdsiek

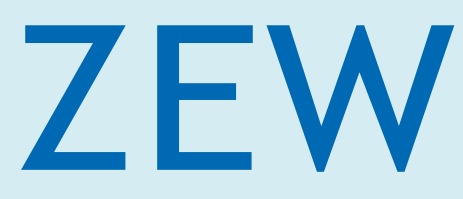

Zentrum für Europäische Wirtschaftsforschung $\mathrm{GmbH}$ Centre for European Economic Research 
Discussion Paper No. 15-087

\title{
Mobile Information and Communication Technologies, Flexible Work Organization and Labor Productivity: Firm-Level Evidence
}

\author{
Steffen Viete and Daniel Erdsiek
}

Download this ZEW Discussion Paper from our ftp server:

http://ftp.zew.de/pub/zew-docs/dp/dp15087.pdf

Die Discussion Papers dienen einer möglichst schnellen Verbreitung von neueren Forschungsarbeiten des ZEW. Die Beiträge liegen in alleiniger Verantwortung der Autoren und stellen nicht notwendigerweise die Meinung des ZEW dar.

Discussion Papers are intended to make results of ZEW research promptly available to other economists in order to encourage discussion and suggestions for revisions. The authors are solely responsible for the contents which do not necessarily represent the opinion of the ZEW. 


\title{
Mobile Information and Communication Technologies, Flexible Work Organization and Labor Productivity: Firm-Level Evidence
}

\author{
Steffen Viete* and Daniel Erdsiek ${ }^{\ddagger}$
}

December 2015

\begin{abstract}
Mobile information and communication technologies (ICT) have started to diffuse rapidly in the business sector. This study tests for the complementarity between the use of mobile ICT and organizational practices providing workplace flexibility. We hypothesize that mobile ICT can create value if organizational practices grant employees appropriate autonomy over when, where and how to perform work-related tasks. Our data set comprises 1132 German service firms and provides information on the share of employees that have been equipped with mobile devices which allow for wireless internet access, such as notebooks, tablets and smartphones. Workplace flexibility is measured in terms of firms' use of working from home arrangements, working time accounts, and trust-based working time. Within a production function framework, we find that the use of mobile ICT is associated with a productivity premium only in firms granting workplace flexibility by means of trust-based working time. Robustness checks suggest that our results are not driven by ICT-skill complementarity or by complementarity of mobile ICT with multiple alternative modern management practices.
\end{abstract}

JEL-Classification: D22, L22, M10, O33.

Keywords: Mobile Information and Communication Technologies, Organizational Practices, Labor Productivity, Complementarity, Firm-Level Data.

* Centre for European Economic Research (ZEW) Mannheim, P.O. Box 103443, 68034 Mannheim, email: viete@zew.de. For further information on projects of the author see www.zew.de/staff_sve.

$\ddagger$ Centre for European Economic Research (ZEW) Mannheim, P.O. Box 103443, 68034 Mannheim, email: erdsiek@zew.de. For further information on projects of the author see www.zew.de/staff_der. We thank Irene Bertschek, Benjamin Engelstätter, Michael Kummer, Fabienne Rasel, Patrick Schulte, as well as participants of the ZEW internal seminars and the 3rd Workshop on Ubiquitous Working for their valuable comments. This paper was written as part of the project "Challenges and Opportunities Arising from Ubiquitous Working" funded by the Leibniz Association. All remaining errors are our own responsibility. 


\section{Introduction}

Mobile information and communication technologies (ICT) connecting to the internet, such as notebooks, tablets and smartphones, have been diffusing into the workplace during recent years. The expansion of mobile ICT marks the next step in the decentralization of computing technologies after the development of the personal computer has relocated computing power from mainframe computers to the workers' desktops in the 1980s (Hitt and Brynjolfsson, 1997) and the diffusion of the internet has granted connectivity in the 1990s. In Germany, the diffusion of these two classical forms of ICT used at the workplace has nearly stagnated by now, as measured by the share of employees working predominantly at a personal computer or having access to the internet (Figure 1). In contrast, the share of employees who have been equipped with mobile ICT devices by their employer has nearly doubled from $12 \%$ to $23 \%$ between 2010 and 2014. The firms' adoption of mobile ICT is driven by dramatically declining prices for mobile ICT and improvements in the wireless infrastructure granting mobile connectivity. In the period from 2010 till 2014, for instance, hedonic prices for notebooks in Germany declined by about 40\% (Statistisches Bundesamt, 2015). Moreover, wireless digital connectivity is continuously improved allowing employees to access internal documents and information, or communicate with customers and business partners from virtually everywhere at any time. As digital communication and information processing is becoming ubiquitous, mobile ICT are widely expected to change how work will be organized in the future, dissolving its temporal and spatial boundaries.

In this study, we investigate the role of mobile ICT for firm performance with a special focus on organizational complements. As previous studies have shown, the returns to ICT investments depend heavily on organizational complements, such as decentralized work organization (Bresnahan et al., 2002). A complementary relationship between generic ICT and decentralized work organization is founded in the difficulties to convey specific knowledge and the constraints to information processing abilities of 'bounded rational' individuals within the firm. As ICT have the capacity to mitigate both by reducing informational frictions and communication costs, these properties are deemed valuable especially when accompanied with respective changes in organizational practices and decision authority (Bloom et al., 2014; Hitt and Brynjolfsson, 1997).

Ubiquitous digital information processing and wireless connectivity are novel features of mobile ICT bearing the potential for enhanced labor productivity. Building on the ICT productivity literature, we hypothesize that mobile ICT can create value if organizational practices grant employees with appropriate decision rights and autonomy over when, where and how to perform work-related tasks. These organizational practices are frequently subsumed under the term workplace flexibility. This notion of complementarity also implies 
Figure 1: Recent Decentralization of Computing Technologies in Germany

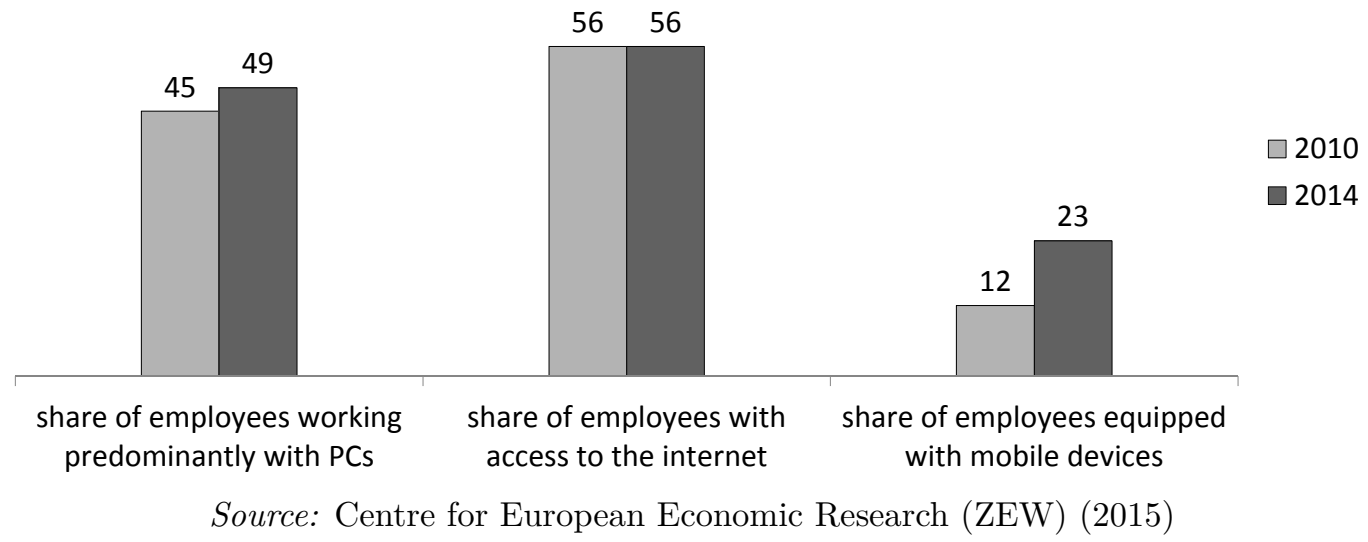

that firms which do not pursue workplace flexibility in their organizational design will experience lower returns to investments in mobile ICT. In order to test wether workplace flexibility is relevant for the efficient use of mobile ICT, we account for complementarities in a production function framework.

To explore our proposition, we gathered detailed survey data on the use of ICT and organizational practices in German service firms. We narrowed down the concept of workplace flexibility to formal organizational practices which grant employees control of their work schedule and hours, as well as flexibility with respect to the place of work. ${ }^{1}$ In particular, we observe whether firms make use of working from home arrangements, working time accounts or trust-based working time. These measures broadly cover the most relevant organizational practices providing for workplace flexibility. They span the temporal and spatial dimension of flexibility and differ by the degree of autonomy granted to the employee.

We find support for complementarity between the use of mobile ICT and workplace flexibility. In particular, our results show that the use of mobile ICT is associated with a productivity premium in firms using trust-based working time. We do not find significant relations between mobile ICT and labor productivity in the absence of trust-based working time. As trust-based working time implies a step towards greater self-management and autonomy, our findings suggest that a high degree of workplace flexibility is crucial for the effective use of mobile ICT. Robustness checks suggest that our results are not driven by ICT-skill complementarity or by complementarity of mobile ICT with a wide variety of alternative modern management practices.

\footnotetext{
${ }^{1}$ In this way, we delineate our analysis form aspects of flexibility that help employers to adapt to changes in supply and demand more quickly, such as part-time employment or reduced working hours, frequently discussed under the concept of external or numerical flexibility. Moreover, the focus of our analysis does not lie on management practices which formally provide for functional flexibility of employees, such as job-rotation (Hempell and Zwick, 2008; Origo and Pagani, 2008).
} 
The remainder of the paper is organized as follows. Section 2 provides a literature review on relevant previous results. Section 3 introduces the data and provides descriptive statistics. Section 4 describes the empirical methodology. Results are described in Section 5 and Section 6 concludes.

\section{Background Discussion}

This study is related to the vast literature on the effects of ICT and modern management practices on firm performance and, more specifically, to the literature on complementarities between ICT and organizational design. Moreover, our analysis is related to studies evaluating work-life balance practices and workplace flexibility.

Positive productivity effects of ICT as general purpose technology, often measured by IT investment, are well-documented at the firm level and the individual level (e.g. Bertschek, 2012; Draca et al., 2007; Kretschmer, 2012). Empirical evidence for more specific technologies, such as broadband technologies, are less conclusive (Bertschek et al., 2013; De Stefano et al., 2014). As mobile ICT have started to diffuse only quite recently, large-scale empirical evidence on their effects on firm performance is scarce. To the best of our knowledge, the only study focussing on productivity effects of mobile ICT is provided by Bertschek and Niebel (2013). They find a positive association between mobile ICT and labor productivity for a sample of German manufacturing and service firms. Their analysis, however, abstracts from potential organizational complements to mobile ICT.

Complementarities between ICT and organizational practices have been found to be a main explanation for heterogenous returns on IT investments. The diffusion of ICT has coincided with radical changes in work organization away form traditional tayloristic organizations to modern management practices emphasizing decentralization of decision authority and supporting incentives. Bresnahan et al. (2002) provide one of the first studies to show that firms can leverage their ICT investment by complementary organizational design. They find that productivity effects of ICT are higher among firms which pursue decentralized decision making and work in teams. ${ }^{2}$ Bloom et al. (2012) show that the higher returns to ICT use of US-based firms compared to firms in Europe can be related to differences in the use of innovative people management practices that emphasize target setting, monitoring, promotion, rewards, hiring, and firing.

Going beyond the treatment of ICT as an homogeneous capital good, some authors highlight that different types of ICT can have distinct implications for performance and organization (Aral and Weill, 2007; Bloom et al., 2014). Only quite recently studies

\footnotetext{
${ }^{2}$ Further studies confirm these complementarity effects in different contexts (e.g. Bartel et al., 2007; Bertschek and Kaiser, 2004; Garicano and Heaton, 2010).
} 
started to explore complementarities between more particular technologies and specific organizational practices they were designed to support. Aral et al. (2012) document productivity effects of human capital management software when used in conjunction with performance pay and human resource analytics practices. Similar three-way complementarities are found between IT use, group-based decentralized decision-making and external focus of the firm (Tambe et al., 2012).

The effective use of mobile ICT supports an increasing decentralization of work with respect to time and place. As summarized by Bloom et al. (2010), decentralization in general involves a tradeoff between principal-agent problems (Prendergast, 2002) and the efficient use of private information favouring delegation and worker autonomy (Radner, 1993). Therefore, workplace flexibility might empower employees to work when and where they are most productive and creative, but could also lead to an increase in shirking. In fact, with regard to the existing literature the overall effects of working environments made up of mobile ICT and flexible working practices are unclear a priory.

Based on case studies and firm surveys, the literature on flexible working practices identifies several potential benefits. ${ }^{3}$ While causal effects of organizational practices are inherently hard to pin down, this literature finds positive associations of flexible working practices with employees' work-life balance, absenteeism, employee turnover and, ultimately, productivity (e.g. Bloom and Van Reenen, 2006; Dalton and Mesch, 1990; Dionne and Dostie, 2007; Hill et al., 2008; Stavrou and Kilaniotis, 2010). Recent experimental evidence is provided by Bloom et al. (2015) who randomly assigned callcenter agents into working from home arrangements. They find considerable performance increases as well as improved work satisfaction induced by working from home. Furthermore, the allocation of authority can have strong motivational effects (Roberts, 2007) and increase commitment. Exploiting German firm level data, Beckmann and Hegedues (2011) and Godart et al. (2014) provide evidence for positive effects of trust-based working time on productivity and innovation.

On the contrary, flexible working practices could also exhibit detrimental effects on productivity related factors. The technology driven availability for work-related purposes outside regular working hours and the interruption of leisure time can evoke work-family conflicts (Boswell and Olson-Buchanan, 2007), reduce job satisfaction or even cause mental strain and other health-related problems (Askenazy and Caroli, 2010). Allowing employees to work at disparate locations and times can furthermore be associated with higher coordination and monitoring costs within the firm (Alonso et al., 2008) and impede the exploitation of potential returns to scale (Thesmar and Thoenig, 2007). Finally, firms using mobile ICT may face costs related to IT-security.

\footnotetext{
${ }^{3}$ See Council of Economic Advisors (2010) or De Menezes and Kelliher (2011) for reviews.
} 
In spite of a growing literature dealing with workplace flexibility in economics, this aspect has yet to be integrated into the IT productivity literature. As performance effects of mobile ICT are not clear to date, our study contributes to a more precise understanding about how these new technologies affect work outcomes and interact with firms' internal organization.

\section{Data}

\subsection{Data Set}

We gathered fine-grained survey data on firms' use of ICT and flexible working practices within the scope of the ICT-Survey by the Centre for European Economic Research (ZEW). ${ }^{4}$ The survey was conducted by computer assisted telephone interviews in 2014/2015 and covers manufacturing and service firms located in Germany. It was stratified according to 17 industries, three size classes and two regions (East/West Germany).

We confine our analysis to firms in the service sector, where knowledge work is a considerable input share and where we expect mobile ICT and the technological opportunities they create to be most relevant. By focusing on a more homogenous population of firms, we attempt to mitigate the problem of unobserved heterogeneity and avoid estimating production processes which are potentially quite heterogenous. After data cleaning and due to item-nonresponse we arrive at a final estimation sample of 1132 observations. Table A.1 displays the industry distribution among the firms in our sample.

\subsection{Measuring ICT}

In this study, we focus on potential productivity effects brought about by the novel features of mobile ICT, i.e. wireless connectivity and ubiquitous digital information processing. Since firms that use mobile ICT might also exhibit a high general ICT intensity, we have to differentiate mobile ICT use from other forms of ICT used at the workplace.

In order to measure the firms' use of mobile ICT, we asked for the share of employees which firms equipped with mobile devices which provide wireless internet access, such as notebooks, smartphones or tablets ( $\%$ emp. using mobile ICT). In addition, we measure the firms' general ICT intensity in terms of the share of employees who work predominantly with a computer (\% emp. working with $P C$ ). This measure is a common proxy for general purpose ICT and has been widely used in the ICT productivity literature (e.g. Bloom et al., 2012; Bresnahan et al., 2002). Finally, the firms' general (mainly fixed-line)

\footnotetext{
${ }^{4}$ See the ZEW Research Data Centre for more information: http://kooperationen.zew.de/en/ zew-fdz/provided-data/zew-ict-survey.html.
} 
internet connectivity is measured by the share of employees who have access to the internet at the workplace (\% emp. internet access). Table A.3 provides an overview and descriptions of the main variables in our analysis.

\subsection{Measuring Workplace Flexibility}

Extending the common organizational practices considered in the ICT productivity literature, we focus on flexible working practices which provide employees discretion over when, where and how to perform work-related tasks. In particular, we consider three generic measures of respective human resource management practices in our analysis.

First, with respect to spatial flexibility, we consider the use of working form home arrangements by the firm. Such arrangements, also discussed under the terms telecommuting or telework, first appeared in the academic discourse in the the 1970s (Nilles, 1975), and have become increasingly common ever since. To date, working form home arrangements are the dominating organizational practice which employers adopt to promote flexibility with regard to the place of work. Based on the question whether employees have the opportunity to work from home regularly, we generate a dummy variable taking the value one if working from home arrangements are used by the firm and zero, otherwise. We employ this variable in order to measure if the firm delegates decision authority to employees over where to perform work-related tasks.

Second, with respect to temporal flexibility, we consider the use of working time accounts. Working time accounts cover a variety of more specific arrangements which involve the accumulation of time credits/debits and differ by the period of time after which employees must balance their accounts. One of the most common forms are flextime arrangements, under which accounts must be balanced on a daily basis and which allow employees to exercise some choice over beginning and end of their workday around some mandatory core hours (Godart et al., 2014). Working time accounts in the form of flextime arrangements started diffusing during the 1960s and marked the onset of working time flexibility in Germany (Beermann and Brenscheidt, 2013). We measure the firms' use of working time accounts by a dummy variable taking the value one if working time accounts are used and zero, otherwise.

Third, we analyze the use of trust-based working time. In contrast to working time accounts, under trust-based working time employers typically completely renounce controlling working hours and grant employees complete discretion over how to manage their workday. They differ from other flexible working arrangements as they involve a transition from working time registration to a management by objectives strategy, i.e. a shift from input control to output control (Beckmann and Hegedues, 2011; Singe and Croucher, 2003). As employees are merely evaluated by their work output, trust-based working time 
imply flexibility along multiple dimensions. They refer to a form of self-managed work involving a high degree of autonomy but are also demanding in terms of self-reliance. Therefore, they arguably constitute the most radical form of workplace flexibility that we consider and that is empirically relevant among German firms today.

By focusing on working form home arrangements, working time accounts and trustbased working time, we consider the most obvious organizational complements to the technological novelty in mobile ICT over more traditional types of ICT. Our measures cover the most relevant organizational practices providing for workplace flexibility and enable us to aptly measure firms' organizational flexibility at large (BMFSFJ, 2013). At the same time, we are able to differentiate between spatial and temporal flexibility, as well as the degree of authority delegation. Thus, we can provide more nuanced insights into how mobile ICT are effectively used and which types of working environments they will likely promote as they continue to diffuse.

\subsection{Descriptive Statistics}

Table 1 provides summary statistics for the main variables of our analysis. On average, the firms have 138 employees and achieved a volume of sales of 0.17 million Euros per employee. The median size of the firms amounts to 25 employees and reflects that our sample largely consists of small and medium sized establishments. The firms' average investment expenditures amount to 1 million Euro and $27 \%$ of the employees obtained a university degree. On average, the employers have equipped a share of $34 \%$ of their employees with mobile ICT devices. $86 \%$ of the firms in our sample use mobile ICT at all. Focusing on the firms' general ICT intensity, $62 \%$ of the employees work predominantly with a $\mathrm{PC}$ and $74 \%$ have access to the internet at the workplace on average.

Figure 2 depicts the incidence of workplace flexibility practices among the firms in our sample. Interestingly, all three practices are equally common, as shown in panel A. Each practice is used by about $60 \%$ of the firms. Disparities in the prevalence of the different forms of workplace flexibility are revealed when looking at the share of employees actually working under the respective arrangement in the average firm in our sample, as shown in panel B. Whereas around $51 \%$ of the employees have working time accounts, only $34 \%$ of the employees work under trust-based working time. About $14 \%$ are working under official working from home arrangements on average. 
Table 1: Summary Statistics

\begin{tabular}{|c|c|c|c|c|}
\hline & Mean & $\mathrm{SD}$ & Min & Max \\
\hline \multicolumn{5}{|l|}{ Labor productivity } \\
\hline sales (in mio. Euro) / employees & 0.17 & 0.32 & 0.006 & 6.000 \\
\hline \multicolumn{5}{|l|}{ Workplace flexibility } \\
\hline trust-based worktime & 0.60 & 0.49 & 0 & 1 \\
\hline working time accounts & 0.62 & 0.49 & 0 & 1 \\
\hline working from home & 0.62 & 0.49 & 0 & 1 \\
\hline \multicolumn{5}{|l|}{ ICT use } \\
\hline \% emp. mobile ICT & 0.34 & 0.33 & 0 & 1 \\
\hline$\%$ emp. working with $\mathrm{PC}$ & 0.62 & 0.37 & 0 & 1 \\
\hline$\%$ emp. internet access & 0.74 & 0.35 & 0 & 1 \\
\hline \multicolumn{5}{|l|}{ Qualification and age structure } \\
\hline$\%$ high-skilled emp. & 0.27 & 0.30 & 0 & 1 \\
\hline \% medium-skilled emp. & 0.58 & 0.29 & 0 & 1 \\
\hline$\%$ emp. below 30 & 0.24 & 0.18 & 0 & 1 \\
\hline \multicolumn{5}{|l|}{ Controls } \\
\hline employees & 138.45 & 697.42 & 1 & 15518 \\
\hline investments (in mio. Euro) & 1.04 & 4.56 & 0 & 90 \\
\hline location in Eastern Germany & 0.29 & 0.45 & 0 & 1 \\
\hline Observations & 1132 & & & \\
\hline
\end{tabular}

Source: ZEW ICT-Survey 2014/2015

Figure 2: Workplace Flexibility Practices
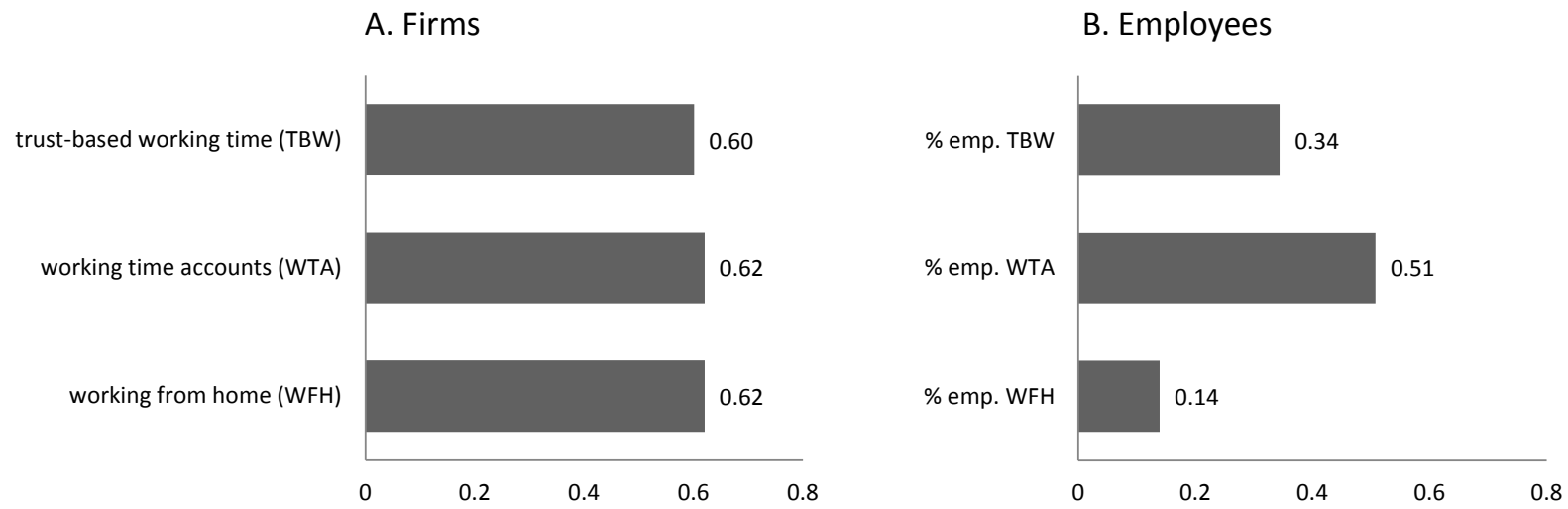

Notes: Panel A shows the averages of the binary variables indicating whether the firm generally offers working from home arrangements, working time accounts and trust-based working time. Panel B provides the averages of the respective shares of employees actually working under the arrangement in the 1132 firms in our estimation sample. Source: ZEW ICT-Survey 2014/2015 


\section{Methodology}

We investigate the hypothesis that the impact of mobile ICT use on firm performance hinges on the firms' organizational complements that are appropriate to take advantage of the novel features of mobile ICT. The seminal paper by Milgrom and Roberts (1990) formalizes this notion of complementarity. It requires that the contribution of (weakly) complementary input factors to a payoff function $\Pi(\cdot)$, such as productivity, is jointly higher (at least equal) than the sum of their individual contributions when implemented in isolation. ${ }^{5}$

$$
\Pi(1,1)-\Pi(0,0) \geq \Pi(1,0)-\Pi(0,0)+\Pi(0,1)-\Pi(0,0)
$$

In principle, the literature has put forward two types of statistical tests for the existence of complementarities between input factors as formalized by the inequality restriction in equation (1). Most commonly, studies test for complementarities indirectly, by looking at correlations between input factors (factor demand equations). If two activities are complements and this is well understood by the firm, one should observe a clustering of adoption decisions. A more direct test for complementarities focuses on analyzing performance differences. This involves testing whether the hypothesized complements are more productive when adopted jointly rather than individually by estimating productivity equations.

Each test tends to have the highest statistical power when the other is weakest. Given mobile ICT and workplace flexibility were actually complements, firms would seek to adopt them jointly. If managers are fully aware of a set of complements and have complete control over the individual factors, we would expect all firms to adopt the system of complements and correlation will be strong. A productivity test, on the contrary, would have little power to identify benefits form adopting the system of complements in this hypothetical situation, as firms would not adopt one complement in isolation. However, in a situation where firms are still experimenting with various practices or do not have full control over any of the complementary factors, correlation of complementary practices would not be perfect but there should be detectable differences in productivity (Aral et al., 2012; Brynjolfsson and Milgrom, 2013).

The latter case is likely more relevant to our application, especially due to the novelty of mobile ICT. As mobile ICT started diffusing to the business sector only recently and wireless internet infrastructure in Germany has matured only over recent years, firms' knowledge of the effective use of these young technologies is likely still limited. Jovanovic and Stolyarov (2000) and Bresnahan et al. (2002) show that complements might be up-

\footnotetext{
${ }^{5}$ See also the discussion by Brynjolfsson and Milgrom (2013).
} 
graded at different times if their identification and implementation involves uncertainty and learning. In addition, we draw from the vast literature on organizational practices and complements, which assumes that organizational practices tend to persist over time and are hard to change for incumbent firms, as justified by high adjustment costs of organizational change (Autor et al., 2002; Milgrom and Roberts, 1990; Tambe et al., 2012). Consequently, when organizational practices are quasi-fix over the short run, managers were not able to act efficiently on them over the diffusion period of mobile ICT. While mobile ICT and relevant organizational complements might not be clustered under these circumstances, their joint impact on productivity will still be measurable. We therefore focus on analysing complementarities within a classical production function framework.

In testing directly for complementarities in production, the literature has primarily built on the Cobb-Douglas production function framework. In line with this literature, our primary regression model is an augmented Cobb-Douglas production function with complementary technology and organizational inputs entered independently and in pairs. It can be written as:

$$
\begin{aligned}
& \ln \left(\frac{Y_{i}}{L_{i}}\right)=\ln \left(A_{i}\right)+\left(\alpha_{L}-1\right) \ln \left(L_{i}\right)+\alpha_{K} \ln \left(K_{i}\right)+\beta_{P C} P C_{i}+\beta_{I A} I A_{i} \\
& +\beta_{\text {mobICT }} \operatorname{mobICT_{i}}+\gamma_{T B W} T B W_{i}+\gamma_{W T A} W T A_{i}+\gamma_{W F H} W F H_{i} \\
& +\left[\delta_{1} T B W_{i}+\delta_{2} W T A_{i}+\delta_{3} W F H_{i}\right] * \operatorname{mobICT_{i}}+\lambda^{\prime} \mathbf{x}_{i}+u_{i}
\end{aligned}
$$

$Y_{i}$ denotes output of firm $i$ measured in sales, which the production function relates to labor $L_{i}$, capital $K_{i}$ and a Hicks-neutral productivity term $A_{i}$. As we do not observe capital inputs, we use investment expenditures to approximate capital, assuming that investments are proportional to the firms' capital stock. Labor is measured by the number of employees. In addition to capital and labor inputs, we augment the production function by our ICT inputs and organizational measures, which account for firms' use of workplace flexibility. As a measure of general ICT intensity, we include the share of employees working predominantly with computers $\left(P C_{i}\right)$ as well as the share of employees with internet access $\left(I A_{i}\right)$. Our key variable of interest is the share of employees equipped with mobile devices $\left(m o b I C T_{i}\right)$. We account for workplace flexibility by three dummy variables indicating wether the firm uses trust-based working time $\left(T B W_{i}\right)$, working time accounts $\left(W T A_{i}\right)$, or working form home arrangements $\left(W F H_{i}\right) . \mathbf{x}_{i}$ represents a vector of control variables and $u_{i}$ is an idiosyncratic error term. As control variables, we include the share of employees with university degree, the share of employees with vocational education, and the share of employees below the age of 30 to account for the skill and age profile of the workforce. Moreover, we include nine industry dummies constructed from 
two digit standard industry codes (NACE) and a dummy indicating whether the firm is located in Eastern Germany.

The $\beta$ and $\gamma$ coefficients capture the main effects of ICT and workplace flexibility. Our primary interest lies in the model parameters $\delta_{1}-\delta_{3}$. If mobile ICT and any type of workplace flexibility form a system of complements reinforcing each other, we would expect $\delta>0$ after controlling for other factors affecting production. We estimate our model by ordinary least squares (OLS) with heteroskedasticity-robust standard errors.

\section{Results}

\subsection{Correlation of Workplace Flexibility and ICT}

Table 2 shows the correlation matrix between key variables in our analysis, i.e. the binary variables indicating whether a firm uses each of the three workplace flexibility practices and our three measures for ICT use at the workplace. We gain two main insights from these correlations.

Firstly, the correlations between the workplace flexibility measures are only moderate and do not provide strong evidence for clusters of practices which firms implement jointly (Ichniowski et al., 1997). Instead, the correlations reflect that the concept of workplace flexibility is multidimensional. Firms implementing one of the observed practices do not necessarily adopt the other practices as well. No correlation is found between the adoption of working time accounts and trust-based working time. This finding is not counterintuitive since the former practice is based on keeping record of working hours whereas the latter disregards the employees' working hours by definition. The use of working from home arrangements is positively correlated with the use of trust-based working time $(r=0.25)$ and working time accounts $(r=0.09)$, however a relevant proportion of firms use just one of these organizational practices, if any. Consequently, we consider them separately in our analysis in order to get a more nuanced picture of which practices are relevant in leveraging investments in mobile ICT.

Secondly, the correlations between organizational measures and ICT variables provide first evidence that firms pursuing workplace flexibility in their organizational design differ from the remaining firms in terms of their ICT use. In line with our hypothesis, general ICT intensity and the share of employees equipped with mobile devices is higher in firms that have implemented workplace flexibility practices. In particular, the use of working form home arrangements and trust-based working time is positively correlated to all three measures of the firms' ICT use. In contrast, the firms' use of working time accounts is not significantly correlated to general ICT intensity. The correlation with mobile ICT is 
Table 2: Correlation of Workplace Flexibility and ICT

\begin{tabular}{lccccc}
\hline \hline & TBW & WTA & WFH & $\begin{array}{c}\text { mobile } \\
\text { ICT }\end{array}$ & PC \\
\hline trust-based worktime (TBW) & 1 & & & & \\
working time accounts (WTA) & -0.001 & 1 & & & \\
working from home (WFH) & $0.247^{* * *}$ & $0.087^{* * *}$ & 1 & & \\
\% emp. mobile ICT & $0.146^{* * *}$ & $-0.063^{* *}$ & $0.224^{* * *}$ & 1 & \\
\% emp. working with PC & $0.193^{* * *}$ & -0.008 & $0.288^{* * *}$ & $0.296^{* * *}$ & 1 \\
$\%$ emp. internet access & $0.181^{* * *}$ & -0.008 & $0.251^{* * *}$ & $0.360^{* * *}$ & $0.740^{* * *}$ \\
\hline \hline
\end{tabular}

Note: Significant at $1 \%^{* * *}$, significant at $5 \%^{* *}$, significant at $10 \%{ }^{*}$.

even significantly negative, but comparably small. Overall, the mainly positive pairwise correlations reflect some joint adoption of mobile ICT and individual practices. While this might be taken as first evidence for complementarities between mobile ICT and workplace flexibility, we focus in the following on the more direct test for complementarities employing a productivity analysis.

\subsection{Main Results}

Table 3 provides the estimation results of the production function model in equation (2). In specification (1), mobile ICT use and the workplace flexibility practices are included separately in the production function. The share of employees equipped with mobile devices by the employer (\% emp. using mobile ICT) is not significantly associated with labor productivity. The respective coefficient is positive, but marginally insignificant at conventional levels. Concerning the measures for workplace flexibility, we find a positive and significant association between the use of trust-based working time and labor productivity. Among firms using trust-based working time the labor productivity is on average 8 percent higher than among firms that have not adopted this flexible work practice. In contrast, for working time accounts and working form home arrangements the estimated coefficients are considerably smaller and statistically insignificant.

In line with the literature, we find a positive association between general ICT intensity, as measured by the share of employees working with a PC, and labor productivity. The share of employees with internet access at the workplace is not significantly related to productivity if the firms' general ICT intensity is taken into account. As a measure for the firms' human capital, the shares of high-skilled and medium-skilled employees are included. The coefficients for both shares are positive and highly significant, with the coefficient for high-skilled employees exceeding the one for medium-skilled employees.

In specifications (2)-(4), we subsequently include an interaction term between mobile ICT and one of the three workplace flexibility measures into the production function. We 
Table 3: Baseline Regression Results

\begin{tabular}{|c|c|c|c|c|c|}
\hline & \multicolumn{5}{|c|}{ Dependent Variable: $\ln ($ sales/employees) } \\
\hline & $(1)$ & $(2)$ & $(3)$ & $(4)$ & $(5)$ \\
\hline \multirow[t]{2}{*}{$\%$ emp. mobile ICT } & 0.114 & -0.089 & 0.020 & 0.007 & -0.223 \\
\hline & $(0.072)$ & $(0.109)$ & $(0.107)$ & $(0.104)$ & $(0.139)$ \\
\hline \multirow[t]{2}{*}{ trust-based worktime (TBW) } & $0.080^{*}$ & -0.021 & $0.081^{*}$ & $0.078^{*}$ & -0.017 \\
\hline & $(0.044)$ & $(0.058)$ & $(0.044)$ & $(0.044)$ & $(0.059)$ \\
\hline \multirow[t]{2}{*}{ working time accounts (WTA) } & 0.009 & 0.012 & -0.046 & 0.009 & -0.045 \\
\hline & $(0.046)$ & $(0.046)$ & $(0.062)$ & $(0.046)$ & $(0.063)$ \\
\hline \multirow[t]{2}{*}{ working from home (WFH) } & 0.044 & 0.041 & 0.044 & -0.003 & 0.021 \\
\hline & $(0.047)$ & $(0.047)$ & $(0.047)$ & $(0.059)$ & $(0.060)$ \\
\hline \multirow[t]{2}{*}{$\%$ emp. mobile $\mathrm{ICT}^{*} \mathrm{TBW}$} & & $0.315^{* *}$ & & & $0.305^{* *}$ \\
\hline & & $(0.131)$ & & & $(0.138)$ \\
\hline \multirow[t]{2}{*}{$\%$ emp. mobile $\mathrm{ICT}^{*} \mathrm{WTA}$} & & & 0.158 & & 0.163 \\
\hline & & & $(0.129)$ & & $(0.130)$ \\
\hline \multirow[t]{2}{*}{$\%$ emp. mobile $\mathrm{ICT}^{*} \mathrm{WFH}$} & & & & 0.167 & 0.069 \\
\hline & & & & $(0.131)$ & $(0.138)$ \\
\hline \multirow[t]{2}{*}{$\%$ emp. working with PC } & $0.300^{* * *}$ & $0.299^{* * *}$ & $0.299^{* * *}$ & $0.298^{* * *}$ & $0.297^{* * *}$ \\
\hline & $(0.098)$ & $(0.098)$ & $(0.098)$ & $(0.098)$ & $(0.097)$ \\
\hline \multirow[t]{2}{*}{$\%$ emp. internet access } & -0.001 & 0.015 & 0.000 & 0.012 & 0.021 \\
\hline & $(0.091)$ & $(0.091)$ & $(0.091)$ & $(0.092)$ & $(0.091)$ \\
\hline \multirow[t]{2}{*}{$\ln ($ employees $)$} & $-0.092^{* * *}$ & $-0.088^{* * *}$ & $-0.092^{* * *}$ & $-0.092^{* * *}$ & $-0.088^{* * *}$ \\
\hline & $(0.024)$ & $(0.024)$ & $(0.024)$ & $(0.024)$ & $(0.024)$ \\
\hline \multirow[t]{2}{*}{$\ln ($ investment $)$} & $0.118^{* * *}$ & $0.116^{* * *}$ & $0.119^{* * *}$ & $0.118^{* * *}$ & $0.117^{* * *}$ \\
\hline & $(0.018)$ & $(0.018)$ & $(0.018)$ & $(0.018)$ & $(0.018)$ \\
\hline \multirow[t]{2}{*}{$\%$ high-skilled emp. } & $0.453^{* * *}$ & $0.449^{* * *}$ & $0.450^{* * *}$ & $0.432^{* * *}$ & $0.437^{* * *}$ \\
\hline & $(0.148)$ & $(0.149)$ & $(0.149)$ & $(0.150)$ & $(0.150)$ \\
\hline \multirow[t]{2}{*}{$\%$ medium-skilled emp. } & $0.270^{* *}$ & $0.266^{* *}$ & $0.257^{* *}$ & $0.260^{* *}$ & $0.248^{*}$ \\
\hline & $(0.127)$ & $(0.128)$ & $(0.126)$ & $(0.128)$ & $(0.128)$ \\
\hline \multirow[t]{2}{*}{ \% emp. below 30} & -0.181 & -0.191 & -0.183 & -0.180 & -0.193 \\
\hline & $(0.126)$ & $(0.125)$ & $(0.126)$ & $(0.126)$ & $(0.126)$ \\
\hline \multirow[t]{2}{*}{ Constant } & $-1.632^{* * *}$ & $-1.616^{* * *}$ & $-1.582^{* * *}$ & $-1.609^{* * *}$ & $-1.556^{* * *}$ \\
\hline & $(0.164)$ & $(0.164)$ & $(0.168)$ & $(0.165)$ & $(0.169)$ \\
\hline Industry \& Regional Dummies & Yes & Yes & Yes & Yes & Yes \\
\hline Adjusted $\mathrm{R}^{2}$ & 0.35 & 0.35 & 0.35 & 0.35 & 0.35 \\
\hline Observations & 1132 & 1132 & 1132 & 1132 & 1132 \\
\hline
\end{tabular}

Note: OLS estimations; Heteroskedasticity-robust standard errors in parentheses; Significant at $1 \%$ ***, significant at $5 \% * *$, significant at $10 \% *$.

find a positive and highly significant coefficient for the interaction term between mobile ICT and the indicator variable for trust-based working time in specification (2). The main effects of mobile ICT and trust-based working time reduce substantially and become insignificant once the interaction term is included in the model. This result suggests that the joint adoption of mobile ICT and workplace flexibility in terms of trust-based working time exhibits positive productivity effects, while a separate adoption does not significantly affect the firm performance. In contrast, the interaction terms with working time accounts (specification 3) and working from home arrangements (specification 4) are positive but 
statistically insignificant. We thus do not find support for complementarities between mobile ICT and these individual practices providing for spatial and temporal flexibility.

Specification (5) provides the estimation results for the full model formulated in equation (2), with all interaction terms between mobile ICT and the workplace flexibility measures entering jointly. The positive coefficient for the interaction term between mobile ICT and trust-based working time remains nearly unchanged and, thus, is robust to the inclusion of the further interaction terms which are again much lower and insignificant. ${ }^{6}$ We do not find any significant main effects for mobile ICT or workplace flexibility measures in this specification.

To illustrate the economic significance of our findings, Figure A.1 provides predictive margins of labor productivity based on the estimation results of specification (5) in Table 3. The margins are predicted by assigning fix values of mobile ICT use and workplace flexibility to all firms in our sample, while retaining observed values for all other covariates. Panel A presents predictive margins for fixed shares of employees using mobile ICT differentiated by the use of trust-based working time. For instance, assuming that firms use trust-based working time and fixing the share of mobile ICT at a value of $20 \%$, we predict a log labor productivity of -2.22 (depicted by the dashed red line).

\subsection{Limitations and Robustness Checks}

So far, our results provide first indicative conditional correlations in support of the hypothesis of complementarity between mobile ICT and workplace flexibility. However, we must be cautious in interpreting our results due to common challenges in testing for complementarities (Athey and Stern, 1998).

Firstly, instead of the joint adoption of mobile ICT and trust-based working time affecting productivity, causality could potentially run in the opposite direction. For instance, firms with a positive productivity shock and improved cash flows might be more likely to invest in new technologies. Likewise, well performing firms might be in a better position to offer their employees the amenity of workplace flexibility.

Secondly, our results could be driven by unobserved factors causing mobile ICT, flexible working practices and productivity to move together. A widely expressed concern in the literature is that unobserved good (human resource) management is causing the joint adoption of new technologies and specific advanced management practices as well as their joint covariance with performance (Bloom and Van Reenen, 2011; Brynjolfsson and Hitt, 2000; Tambe et al., 2012).

\footnotetext{
${ }^{6}$ An F-test on the joint significance of all three interaction terms in specification (5) supports joint significance at the five percent level.
} 
Concerning the endogeneity of organizational practices in our model, we follow most of the literature and assume that organizational practices are quasi-fix over the short run. $^{7}$ In this vein, we assume that firms' organizational design only changed marginally during the short diffusion period of mobile ICT and does not constitute a choice variables in our model. ${ }^{8}$ In this sense, one can interpret our regressions as assessing whether firm differences in organizational design, which existed prior to the diffusion of mobile ICT, affect the returns from using these technologies (Aral et al., 2012). Still, one might be particularly concerned about endogeneity of mobile ICT in our production function.

As a robustness check of our results, we address the problem of omitted variable bias. In particular, we focus on the issue that the positive coefficient on the interaction term $(\delta)$ might pick up unobserved management and organizational practices other than workplace flexibility. Our data include information on additional 'modern' managerial practices, which have been used to assess management quality of the firm (Bloom and van Reenen, 2007) and have frequently been analyzed in the ICT productivity literature and the personnel economics literature (Bartel et al., 2007; Black and Lynch, 2001; Cappelli and Neumark, 2001; Ichniowski and Shaw, 2003; Ichniowski et al., 1997). These management practices contrast with traditional hierarchical organization and emphasize decentralization of decision authority, incentives and target setting, monitoring and multitasking. Besides workplace flexibility, they have been characteristic for organizational change taking place since the 1990s. We augment our model in equation (2) by interactions of mobile ICT with these management practices in order to contrast workplace flexibility from possibly confounding managerial and organizational practices that could have biased our previous results.

Table A.2 provides summary statistics on the indicator variables for additional management and organizational practices we are able to take into account. We observe whether the firm rewards employees based on effort by the use of incentive pay. We moreover take into account the existence of business units with own profit and loss responsibility, such as profit centers, which has been used to proxy general decentralization of decision authority below central management (Acemoglu et al., 2007). We account for target setting and monitoring by the firms' use of regular objective agreements and written performance appraisals. Finally, we observe whether the firm makes use of job rotation models to develop the employees' functional flexibility.

In the columns (1)-(5) in Table 4 we augment our baseline specifications (provided in Table 3) by the interactions between mobile ICT and the measures on managerial and

\footnotetext{
${ }^{7}$ See the discussion in section 4 .

${ }^{8}$ This assumption is supported by several studies showing that the use of many flexible working arrangements, such as working form home or trust-based working time remained largely constant in Germany over recent years (Brenke, 2014; BMFSFJ, 2013).
} 
Table 4: Robustness Tests

\begin{tabular}{|c|c|c|c|c|c|c|}
\hline & \multicolumn{6}{|c|}{ Dependent Variable: $\ln$ (sales/employees) } \\
\hline & $(1)$ & $(2)$ & (3) & $(4)$ & $(5)$ & $(6)$ \\
\hline$\%$ emp. mobile ICT & $\begin{array}{c}0.084 \\
(0.108)\end{array}$ & $\begin{array}{l}-0.101 \\
(0.139)\end{array}$ & $\begin{array}{c}0.011 \\
(0.122)\end{array}$ & $\begin{array}{l}-0.000 \\
(0.124)\end{array}$ & $\begin{array}{l}-0.220 \\
(0.151)\end{array}$ & $\begin{array}{l}-0.213 \\
(0.145)\end{array}$ \\
\hline trust-based worktime (TBW) & $\begin{array}{c}0.072 \\
(0.044)\end{array}$ & $\begin{array}{l}-0.031 \\
(0.058)\end{array}$ & $\begin{array}{l}0.073^{*} \\
(0.044)\end{array}$ & $\begin{array}{c}0.070 \\
(0.044)\end{array}$ & $\begin{array}{l}-0.029 \\
(0.059)\end{array}$ & $\begin{array}{l}-0.018 \\
(0.059)\end{array}$ \\
\hline working time accounts (WTA) & $\begin{array}{l}-0.002 \\
(0.047)\end{array}$ & $\begin{array}{c}0.001 \\
(0.047)\end{array}$ & $\begin{array}{l}-0.059 \\
(0.065)\end{array}$ & $\begin{array}{l}-0.002 \\
(0.047)\end{array}$ & $\begin{array}{l}-0.063 \\
(0.065)\end{array}$ & $\begin{array}{l}-0.045 \\
(0.063)\end{array}$ \\
\hline working from home (WFH) & $\begin{array}{c}0.034 \\
(0.048)\end{array}$ & $\begin{array}{c}0.032 \\
(0.048)\end{array}$ & $\begin{array}{c}0.034 \\
(0.048)\end{array}$ & $\begin{array}{l}-0.015 \\
(0.061)\end{array}$ & $\begin{array}{c}0.006 \\
(0.062)\end{array}$ & $\begin{array}{c}0.019 \\
(0.062)\end{array}$ \\
\hline$\%$ emp. mobile ICT $*$ TBW & & $\begin{array}{l}0.324^{* *} \\
(0.134)\end{array}$ & & & $\begin{array}{l}0.316^{* *} \\
(0.142)\end{array}$ & $\begin{array}{l}0.305^{* *} \\
(0.138)\end{array}$ \\
\hline$\%$ emp. mobile $\mathrm{ICT} * \mathrm{WTA}$ & & & $\begin{array}{c}0.164 \\
(0.141)\end{array}$ & & $\begin{array}{c}0.182 \\
(0.141)\end{array}$ & $\begin{array}{c}0.162 \\
(0.129)\end{array}$ \\
\hline$\%$ emp. mobile ICT $*$ WFH & & & & $\begin{array}{c}0.174 \\
(0.135)\end{array}$ & $\begin{array}{c}0.090 \\
(0.142)\end{array}$ & $\begin{array}{c}0.079 \\
(0.147)\end{array}$ \\
\hline incentive pay (IP) & $\begin{array}{c}0.094 \\
(0.061)\end{array}$ & $\begin{array}{c}0.098 \\
(0.061)\end{array}$ & $\begin{array}{c}0.096 \\
(0.061)\end{array}$ & $\begin{array}{c}0.098 \\
(0.061)\end{array}$ & $\begin{array}{l}0.102^{*} \\
(0.061)\end{array}$ & \\
\hline job rotation $(\mathrm{JR})$ & $\begin{array}{l}-0.089 \\
(0.075)\end{array}$ & $\begin{array}{l}-0.089 \\
(0.075)\end{array}$ & $\begin{array}{l}-0.083 \\
(0.076)\end{array}$ & $\begin{array}{l}-0.086 \\
(0.075)\end{array}$ & $\begin{array}{l}-0.081 \\
(0.076)\end{array}$ & \\
\hline profit center $(\mathrm{PR})$ & $\begin{array}{l}0.096 \\
(0.071)\end{array}$ & $\begin{array}{c}0.100 \\
(0.071)\end{array}$ & $\begin{array}{l}0.101 \\
(0.071)\end{array}$ & $\begin{array}{c}0.103 \\
(0.072)\end{array}$ & $\begin{array}{c}0.109 \\
(0.071)\end{array}$ & \\
\hline objective agreements $(\mathrm{OA})$ & $\begin{array}{c}0.073 \\
(0.078)\end{array}$ & $\begin{array}{c}0.083 \\
(0.077)\end{array}$ & $\begin{array}{l}0.079 \\
(0.078)\end{array}$ & $\begin{array}{c}0.079 \\
(0.078)\end{array}$ & $\begin{array}{c}0.092 \\
(0.078)\end{array}$ & \\
\hline performance appraisals (PA) & $\begin{array}{c}0.008 \\
(0.076)\end{array}$ & $\begin{array}{l}0.006 \\
(0.076)\end{array}$ & $\begin{array}{c}0.013 \\
(0.077)\end{array}$ & $\begin{array}{c}0.012 \\
(0.077)\end{array}$ & $\begin{array}{c}0.014 \\
(0.077)\end{array}$ & \\
\hline$\%$ emp. mobile $\mathrm{ICT} *$ IP & $\begin{array}{c}0.009 \\
(0.130)\end{array}$ & $\begin{array}{l}-0.018 \\
(0.130)\end{array}$ & $\begin{array}{l}0.006 \\
(0.130)\end{array}$ & $\begin{array}{l}-0.009 \\
(0.130)\end{array}$ & $\begin{array}{l}-0.029 \\
(0.130)\end{array}$ & \\
\hline$\%$ emp. mobile ICT $*$ JR & $\begin{array}{l}-0.069 \\
(0.192)\end{array}$ & $\begin{array}{l}-0.080 \\
(0.192)\end{array}$ & $\begin{array}{l}-0.083 \\
(0.195)\end{array}$ & $\begin{array}{l}-0.077 \\
(0.190)\end{array}$ & $\begin{array}{l}-0.100 \\
(0.194)\end{array}$ & \\
\hline$\%$ emp. mobile $\mathrm{ICT} * \mathrm{PR}$ & $\begin{array}{c}0.032 \\
(0.149)\end{array}$ & $\begin{array}{c}0.011 \\
(0.146)\end{array}$ & $\begin{array}{c}0.015 \\
(0.148)\end{array}$ & $\begin{array}{c}0.015 \\
(0.148)\end{array}$ & $\begin{array}{l}-0.017 \\
(0.145)\end{array}$ & \\
\hline$\%$ emp. mobile $\mathrm{ICT} * \mathrm{OA}$ & $\begin{array}{l}-0.079 \\
(0.161)\end{array}$ & $\begin{array}{l}-0.105 \\
(0.158)\end{array}$ & $\begin{array}{l}-0.097 \\
(0.164)\end{array}$ & $\begin{array}{l}-0.102 \\
(0.163)\end{array}$ & $\begin{array}{l}-0.137 \\
(0.163)\end{array}$ & \\
\hline$\%$ emp. mobile $\mathrm{ICT} * \mathrm{PA}$ & $\begin{array}{c}0.045 \\
(0.161)\end{array}$ & $\begin{array}{c}0.069 \\
(0.161)\end{array}$ & $\begin{array}{c}0.025 \\
(0.165)\end{array}$ & $\begin{array}{c}0.039 \\
(0.160)\end{array}$ & $\begin{array}{l}0.044 \\
(0.164)\end{array}$ & \\
\hline \% high-skilled emp. (HSE) & $\begin{array}{c}0.462^{* * *} \\
(0.151)\end{array}$ & $\begin{array}{c}0.461^{* * *} \\
(0.151)\end{array}$ & $\begin{array}{c}0.463^{* * *} \\
(0.151)\end{array}$ & $\begin{array}{c}0.444^{* * *} \\
(0.152)\end{array}$ & $\begin{array}{c}0.453^{* * *} \\
(0.151)\end{array}$ & $\begin{array}{c}0.458^{* * *} \\
(0.165)\end{array}$ \\
\hline$\%$ emp. mobile ICT $* \%$ HSE & & & & & & $\begin{array}{l}-0.046 \\
(0.206)\end{array}$ \\
\hline \% emp. working with $\mathrm{PC}$ & $\begin{array}{c}0.290^{* * *} \\
(0.099)\end{array}$ & $\begin{array}{c}0.290^{* * *} \\
(0.099)\end{array}$ & $\begin{array}{c}0.291^{* * *} \\
(0.099)\end{array}$ & $\begin{array}{c}0.290^{* * *} \\
(0.099)\end{array}$ & $\begin{array}{c}0.291^{* * *} \\
(0.098)\end{array}$ & $\begin{array}{c}0.297^{* * *} \\
(0.097)\end{array}$ \\
\hline$\%$ emp. internet access & $\begin{array}{l}-0.031 \\
(0.092)\end{array}$ & $\begin{array}{c}-0.017 \\
(0.093)\end{array}$ & $\begin{array}{l}-0.033 \\
(0.092)\end{array}$ & $\begin{array}{l}-0.022 \\
(0.093)\end{array}$ & $\begin{array}{c}-0.016 \\
(0.093)\end{array}$ & $\begin{array}{c}0.018 \\
(0.092)\end{array}$ \\
\hline Constant & $\begin{array}{c}-1.611^{* * *} \\
(0.165)\end{array}$ & $\begin{array}{c}-1.599^{* * *} \\
(0.165)\end{array}$ & $\begin{array}{c}-1.566^{* * *} \\
(0.168)\end{array}$ & $\begin{array}{c}-1.593^{* * *} \\
(0.167)\end{array}$ & $\begin{array}{c}-1.540^{* * *} \\
(0.169)\end{array}$ & $\begin{array}{c}-1.556^{* * *} \\
(0.169)\end{array}$ \\
\hline $\ln (\mathrm{emp}) \& \ln (\mathrm{inv})$ & Yes & Yes & Yes & Yes & Yes & Yes \\
\hline$\%$ med.-skilled \& $\%$ below 30 & Yes & Yes & Yes & Yes & Yes & Yes \\
\hline Industry \& Regional Dummies & Yes & Yes & Yes & Yes & Yes & Yes \\
\hline Adjusted $\mathrm{R}^{2}$ & 0.35 & 0.35 & 0.35 & 0.35 & 0.35 & 0.35 \\
\hline Observations & 1132 & 1132 & 1132 & 1132 & 1132 & 1132 \\
\hline
\end{tabular}

Note: OLS estimations; Heteroskedasticity-robust standard errors in parentheses; Significant at 1\% ${ }^{* * *}$, significant at $5 \%^{* *}$, significant at $10 \%^{*}$. 
organizational practices we can account for. We find that, conditional on the additional management interactions our previous results remain unaffected. While the use of mobile ICT is positively and significantly associated with labor productivity when firms use trustbased working time, it is not when firms have adopted any other advanced management practice we consider. Moreover, the coefficient for the mob ICT * TBW interaction term remains similar in magnitude to our baseline results. Hence, this robustness check imposes further restrictions on any unobserved third factor that could bias our findings in support of complementarity between mobile ICT and trust-based working time. Such factor would have to drive the use of mobile ICT, trust-based working time, and firms' productivity simultaneously, but at the same time would have to be unrelated to any other form of managerial practice we consider.

In specification (6) presented in Table 4, we perform a further check of our main findings. It refers to the vast literature showing that new technologies, and ICT in particular, are complementary with skills (Autor et al., 2003). While we accounted for the skill profile of the workforce throughout all our estimations, we now include an additional interaction term between mobile ICT use and the share of high-skilled employees. We thereby test whether it is actually the simultaneous presence of mobile ICT and a skilled workforce in firms using trust-based working time that drives our findings. The results show that the coefficient for the additional interaction term is insignificant, while our previous findings remain unaffected. We thus assume that our main findings do not reflect complementarity of mobile ICT with skills. Overall, our findings in support of complementarity between mobile ICT and workplace flexibility remain robust in the additional checks we have put together thus far.

\section{Conclusion and Future Research}

In this study, we test for the complementarity between the use of mobile ICT and organizational practices providing workplace flexibility. We hypothesize that mobile ICT can create value if organizational practices grant employees more autonomy over when, where and how to perform work-related tasks. In line with our hypothesis, we find a positive association between mobile ICT and labor productivity in firms which delegate decision authority over the execution of work-related tasks in the form of trust-based working time. We find no significant association with labor productivity when the two are adopted separately. As trust-based working time implies a step towards greater self-management and autonomy, our findings suggest that a high degree of workplace flexibility is crucial for the effective use of mobile ICT. Robustness checks suggest that our results are not driven by 
ICT-skill complementarity or by complementarity of mobile ICT with multiple alternative modern management practices.

Our analysis suffers from several limitations, which we have to leave to future research. Most importantly, while our study constitutes a first descriptive approach to the use of mobile ICT in the context of work organization, we cannot fully account for unobserved heterogeneity or reverse causation which might bias our findings. Despite the extensive list of background characteristics we are able to take into account, the investment into mobile ICT in particular is possibly endogenous in our productivity equations.

Our ongoing research will attempt to allow for endogeneity of mobile ICT by exploiting exogenous variation. Future panel analysis might be another step to approaching a more causal interpretation of our results. Still, even at the current stage our research provides first important insights into the diffusion process of mobile ICT and their relation to firm performance and work organization. Our analysis poses a first step in attaining a better understanding of the effective use of these rapidly diffusing technologies and how they might shape our working environment in the future. 


\section{Appendix}

Table A.1: Industry Distribution

\begin{tabular}{llcc}
\hline \hline & NACE Rev. 2 & $\mathrm{N}$ & Percentage \\
\hline Retail Trade & 45,47 & 137 & 12.10 \\
Wholesale Trade & 46 & 111 & 9.81 \\
Transport Services & $49-53,79$ & 133 & 11.75 \\
Media Services & $18,58-60$ & 98 & 8.66 \\
ICT Services & $61-63$ & 127 & 11.22 \\
Financial Services & $64-66$ & 122 & 10.78 \\
Consulting, Advertising & $69,702,73$ & 143 & 12.63 \\
Technical Services & $71-72$ & 119 & 10.51 \\
Business Services & $74,78,80-82$ & 142 & 12.54 \\
\hline Total & & 1132 & 100 \\
\hline \hline
\end{tabular}

Source: ZEW ICT-Survey 2014/2015

Table A.2: Management Practices

\begin{tabular}{lcccc}
\hline \hline & Mean & SD & Min & Max \\
\hline incentive pay & 0.51 & 0.50 & 0 & 1 \\
job rotation & 0.19 & 0.39 & 0 & 1 \\
profit center & 0.31 & 0.46 & 0 & 1 \\
objective agreements & 0.45 & 0.50 & 0 & 1 \\
performance appraisals & 0.38 & 0.49 & 0 & 1 \\
\hline Observations & 1132 & & & \\
\hline \hline
\end{tabular}

Source: ZEW ICT Survey 2014/2015 
Table A.3: Variable Descriptions

\begin{tabular}{|c|c|}
\hline Variable & Description/Question \\
\hline \multicolumn{2}{|l|}{ Dependent variable } \\
\hline $\ln ($ sales/employees $)$ & logarithm of labor productivity [sales (in mio. Euro) / no. of employees] \\
\hline \multicolumn{2}{|l|}{ Workplace flexibility } \\
\hline trust-based worktime & $\begin{array}{l}\text { Does your company use trust-based working time, i.e. self-reliant organiza- } \\
\text { tion of working time without recording of working time by the company? }\end{array}$ \\
\hline working time accounts & $\begin{array}{l}\text { Are there any regulations in your company related to working time ac- } \\
\text { counts, i.e. everything in between flex time and annual working hours } \\
\text { agreements? }\end{array}$ \\
\hline working from home & $\begin{array}{l}\text { Do you offer your employees the opportunity to work from home regularly, } \\
\text { so called working from home arrangements? }\end{array}$ \\
\hline \multicolumn{2}{|l|}{ ICT use } \\
\hline$\%$ emp. mobile ICT & $\begin{array}{l}\text { What share of your employees has been equipped with mobile devices } \\
\text { which allow for wireless internet access, such as notebooks, tablets and } \\
\text { smartphones? }\end{array}$ \\
\hline \% emp. working with PC & $\begin{array}{l}\text { What share of your employees works predominantly with a computer at } \\
\text { the workplace? }\end{array}$ \\
\hline$\%$ emp. internet access & What share of your employees has access to the internet at the workplace? \\
\hline \multicolumn{2}{|l|}{ Qualification and age } \\
\hline \% high-skilled emp. & Share of employees holding university, college or polytechnical degree \\
\hline$\%$ medium-skilled emp. & $\begin{array}{l}\text { Share of employees having completed apprenticeship or holding technical } \\
\text { degrees }\end{array}$ \\
\hline$\%$ emp. below 30 & Share of employees under the age of 30 \\
\hline \multicolumn{2}{|c|}{ Management practices } \\
\hline \multicolumn{2}{|c|}{ Does your company employ any of the following human resource management practices? } \\
\hline incentive pay & Performance-related pay \\
\hline job rotation & Job rotation \\
\hline profit center & Cost/profit autonomy, profit centers \\
\hline objective agreements & Regular written objective agreements \\
\hline performance appraisals & Regular written performance appraisals \\
\hline
\end{tabular}

Source: ZEW ICT-Survey 2014/2015 
Figure A.1: Predictive Margins based on Specification (5) in Table 3
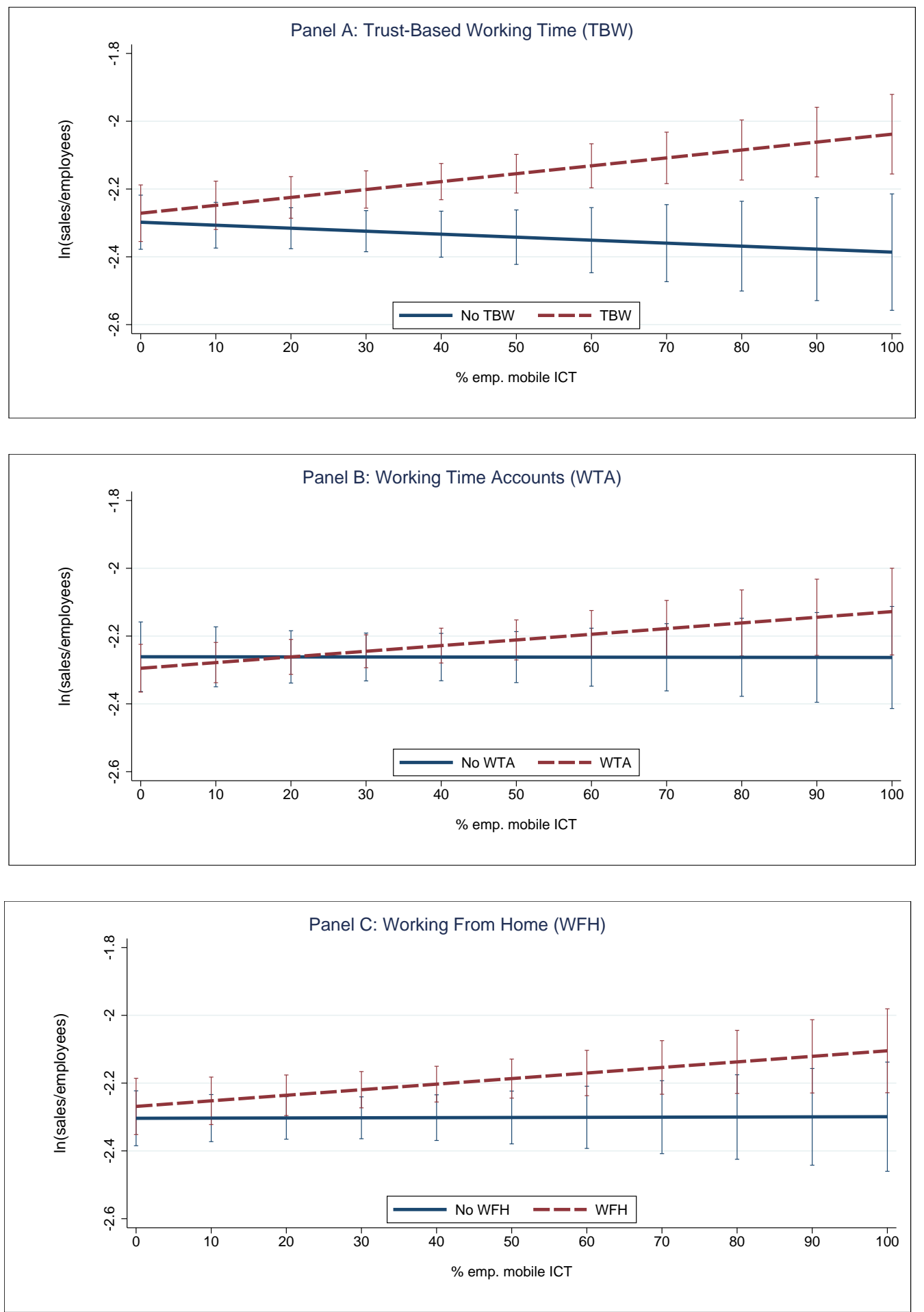

Note: Predictive margins are computed using the margins command in Stata and are based on the estimation results of specification (5) in Table 3. The margins are predicted by assigning fix values of mobile ICT use and workplace flexibility to all firms in our sample, while retaining observed values for all other covariates. In Panel A, the solid blue line depicts the predictive margins if all firms are treated as they would not use trustbased working time. The dashed red line shows margins predicted under the assumption that all firms use trust-based working time. Panel B focuses on the firms' use of working time accounts and Panel $\mathrm{C}$ focuses on the firms' use of working from home arrangements in combination to the use of mobile ICT. The vertical lines indicate the $95 \%$ Confidence Intervals for the point estimates. 


\section{References}

Acemoglu, D., Aghion, P., Lelarge, C., Van Reenen, J., and Zilibotti, F. (2007). Technology, Information, and the Decentralization of the Firm. Quarterly Journal of Economics, 122(4):1759-1799.

Alonso, R., Dessein, W., and Matouschek, N. (2008). When does Coordination Require Centralization? American Economic Review, 98(1):145-179.

Aral, S., Brynjolfsson, E., and Wu, L. (2012). Three-Way Complementarities: Performance Pay, HR Analytics and Information Technology. Management Science, 58(5):913-931.

Aral, S. and Weill, P. (2007). IT Assets, Organizational Capabilities, and Firm Performance: How Resource Allocations and Organizational Differences Explain Performance Variation. Organization Science, 18(5):763-780.

Askenazy, P. and Caroli, E. (2010). Innovative Work Practices, Information Technologies, and Working Conditions: Evidence for France. Industrial Relations: A Journal of Economy and Society, 49(4):544-565.

Athey, S. and Stern, S. (1998). An Empirical Framework for Testing Theories About Complimentarity in Organizational Design. NBER Working Paper No. 6600.

Autor, D. H., Levy, F., and Murnane, R. J. (2002). Upstairs, Downstairs: Computers and Skills on two Floors of a Large Bank. Industrial \& Labor Relations Review, 55(3):432447.

Autor, D. H., Levy, F., and Murnane, R. J. (2003). The Skill Content of Recent Technological Change: An Empirical Exploration. Quarterly Journal of Economics, 118(4):12791333.

Bartel, A., Ichniowski, C., and Shaw, K. (2007). How Does Information Technology Affect Productivity? Plant-Level Comparisons of Product Innovation, Process Improvement, and Worker Skills. Quarterly Journal of Economics, 122(4):1721-1758.

Beckmann, M. and Hegedues, I. (2011). Trust-Based Working Time and Organizational Performance: Evidence from German Establishment-Level Panel Data. WWZ Discussion Paper No. 2011/13.

Beermann, B. and Brenscheidt, F. (2013). Im Takt? Risiken, Chancen und Gestaltung von flexiblen Arbeitszeitmodellen. Bundesanstalt für Arbeitsschutz und Arbeitsmedizin, Dortmund. 
Bertschek, I. (2012). ICT, Internet and Worker Productivity. In Durlauf, S. N. and Blume, L. E., editors, The New Palgrave Dictionary of Economics, Online Edition.

Bertschek, I., Cerquera, D., and Klein, G. J. (2013). More Bits - More Bucks? Measuring the Impact of Broadband Internet on Firm Performance. Information Economics and Policy, 25(3):190-203.

Bertschek, I. and Kaiser, U. (2004). Productivity Effects of Organizational Change: Microeconometric Evidence. Management Science, 50(3):394-404.

Bertschek, I. and Niebel, T. (2013). Mobile and More Productive? Firm-Level Evidence on the Productivity Effects of Mobile Internet Use at the Early Stage of Diffusion. ZEW Discussion Paper No. 13-118.

Black, S. E. and Lynch, L. M. (2001). How to Compete: The Impact of Workplace Practices and Information Technology on Productivity. Review of Economics and Statistics, 83(3):434-445.

Bloom, N., Garicano, L., Sadun, R., and Van Reenen, J. (2014). The Distinct Effects of Information Technology and Communication Technology on Firm Organization. Management Science, 60(12):2859-2885.

Bloom, N., Liang, J., Roberts, J., and Ying, Z. J. (2015). Does Working from Home Work? Evidence from a Chinese Experiment. Quarterly Journal of Economics, 130(1):165-218.

Bloom, N., Sadun, R., and Van Reenen, J. (2010). Recent Advances in the Empirics of Organizational Economics. Annual Review of Economics, 2(1):105-137.

Bloom, N., Sadun, R., and Van Reenen, J. (2012). Americans Do IT Better: US Multinationals and the Productivity Miracle. American Economic Review, 102(1):167-201.

Bloom, N. and Van Reenen, J. (2006). Management Practices, Work-Life Balance, and Productivity: A Review of Some Recent Evidence. Oxford Review of Economic Policy, 22(4):457-482.

Bloom, N. and van Reenen, J. (2007). Measuring and Explaining Management Practices Across Firms and Countries. Quarterly Journal of Economics, 122(4):1351-1408.

Bloom, N. and Van Reenen, J. (2011). Human Resource Management and Productivity. Handbook of Labor Economics, 4:1697-1767.

BMFSFJ (2013). Unternehmensmonitor Familienfreundlichkeit 2013. Bundesministerium für Familie, Senioren, Frauen und Jugend (BMFSFJ). 
Boswell, W. R. and Olson-Buchanan, J. B. (2007). The Use of Communication Technologies after Hours: The Role of Work Attitudes and Work-Life Conflict. Journal of Management, 33(4):592-610.

Brenke, K. (2014). Heimarbeit: Immer weniger Menschen in Deutschland gehen ihrem Beruf von zu Hause aus nach. DIW-Wochenbericht, 81(8):131-139.

Bresnahan, T. F., Brynjolfsson, E., and Hitt, L. M. (2002). Information Technology, Workplace Organization, and the Demand for Skilled Labor: Firm-Level Evidence. Quarterly Journal of Economics, 117(1):339-376.

Brynjolfsson, E. and Hitt, L. M. (2000). Beyond Computation: Information Technology, Organizational Transformation and Business Performance. Journal of Economic Perspectives, 14(4):23-48.

Brynjolfsson, E. and Milgrom, P. (2013). Complementarity in Organizations. In Gibbons, R. and Roberts, J., editors, Handbook of Organizational Economics, pages 11-55. Princeton University Press, Princeton, NJ.

Cappelli, P. and Neumark, D. (2001). Do "High-Performance" Work Practices Improve Establishment-Level Outcomes? Industrial \& Labor Relations Review, 54(4):737-775.

Centre for European Economic Research (ZEW) (2015). Industrie 4.0: Digitale (R)Evolution der Wirtschaft. ZEW IKT-Report, Mannheim.

Council of Economic Advisors (2010). Work-life Balance and the Economics of Workplace Flexibility.

Dalton, D. R. and Mesch, D. J. (1990). The Impact of Flexible Scheduling on Employee Attendance and Turnover. Administrative Science Quarterly, 135(2):370-387.

De Menezes, L. M. and Kelliher, C. (2011). Flexible Working and Performance: A Systematic Review of the Evidence for a Business Case. International Journal of Management Reviews, 13(4):452-474.

De Stefano, T., Kneller, R., and Timmis, J. (2014). The (Fuzzy) Digital Divide: The Effect of Broadband Internet Use on UK Firm Performance. University of Nottingham Discussion Papers in Economics No. 14/06.

Dionne, G. and Dostie, B. (2007). New Evidence on the Determinants of Absenteeism Using Linked Employer-Employee Data. Industrial \& Labor Relations Review, 61(1):108120. 
Draca, M., Sadun, R., and Van Reenen, J. (2007). Productivity and ICTs: A Review of the Evidence. In Mansell, R., Avgerou, C., and Silverstone, R., editors, The $O x$ ford Handbook of Information and Communication Technologies, pages 100-147. Oxford University Press, Oxford.

Garicano, L. and Heaton, P. (2010). Information Technology, Organization, and Productivity in the Public Sector: Evidence From Police Departments. Journal of Labor Economics, 28(1):167-201.

Godart, O., Görg, H., and Hanley, A. (2014). Trust-Based Work-Time and Product Improvements: Evidence from Firm Level Data. IZA Discussion Paper No. 8097.

Hempell, T. and Zwick, T. (2008). New Technology, Work Organisation, and Innovation. Economics of Innovation and New Technology, 17(4):331-354.

Hill, J. E., Jacob, J. I., Shannon, L. L., Brennan, R. T., Blanchard, V. L., and Martinengo, G. (2008). Exploring the Relationship of Workplace Flexibility, Gender, and Life Stage to Family-To-Work Conflict, and Stress and Burnout. Community, Work and Family, 11(2):165-181.

Hitt, L. M. and Brynjolfsson, E. (1997). Information Technology and Internal Firm Organization: An Exploratory Analysis. Journal of Management Information Systems, 14(2):81-101.

Ichniowski, C. and Shaw, K. (2003). Beyond Incentive Pay: Insiders' Estimates of the Value of Complementary Human Resource Management Practices. Journal of Economic Perspectives, 17(1):155-180.

Ichniowski, C., Shaw, K., and Prennushi, G. (1997). The Effects of Human Resource Management Practices on Productivity: A Study of Steel Finishing Lines. American Economic Review, 87(3):291-313.

Jovanovic, B. and Stolyarov, D. (2000). Optimal Adoption of Complementary Technologies. American Economic Review, 90(1):15-29.

Kretschmer, T. (2012). Information and Communication Technologies and Productivity Growth: A Survey of the Literature. OECD Digital Economy Paper No. 195.

Milgrom, P. and Roberts, J. (1990). The Economics of Modern Manufacturing: Technology, Strategy, and Organization. American Economic Review, 80(3):511-28.

Nilles, J. M. (1975). Telecommunications and Organizational Decentralization. IEEE Transactions on Communications, 23(10):1142-1147. 
Origo, F. and Pagani, L. (2008). Workplace Flexibility and Job Satisfaction: Some Evidence from Europe. International Journal of Manpower, 29(6):539-566.

Prendergast, C. (2002). The Tenuous Trade-Off Between Risk and Incentives. Journal of Political Economy, 110(5):1071-1102.

Radner, R. (1993). The Organization of Decentralized Information Processing. Econometrica, 61(5):1109-1146.

Roberts, J. (2007). The Modern Firm: Organizational Design for Performance and Growth. Oxford University Press, Oxford.

Singe, I. and Croucher, R. (2003). The Management of Trust-Based Working Time in Germany. Personnel Review, 32(4):492-509.

Statistisches Bundesamt (2015). Index der Erzeugerpreise gewerblicher Produkte (Inlandsabsatz) nach dem Güterverzeichnis für Produktionsstatistiken. Lange Reihen der Fachserie 17, Reihe 2 von Januar 2000 bis April 2015.

Stavrou, E. and Kilaniotis, C. (2010). Flexible Work and Turnover: An Empirical Investigation Across Cultures. British Journal of Management, 21(2):541-554.

Tambe, P., Hitt, L. M., and Brynjolfsson, E. (2012). The Extroverted Firm: How External Information Practices Affect Innovation and Productivity. Management Science, $58(5): 843-859$.

Thesmar, D. and Thoenig, M. (2007). From Flexibility to Insecurity: How Vertical Separation Amplifies Firm-Level Uncertainty. Journal of the European Economic Association, 5(6):1161-1202. 